\title{
Decoding the heterogeneous landscape in the development prostate cancer (Review)
}

\author{
YENIFER YAMILE SEGURA-MORENO ${ }^{1,2}$, MARÍA CAROLINA SANABRIA-SALAS ${ }^{1}$, \\ RODOLFO VARELA ${ }^{3,4}$, JORGE ANDRÉS MESA ${ }^{5}$ and MARTHA LUCIA SERRANO ${ }^{1,2}$ \\ ${ }^{1}$ Cancer Biology Research Group, National Institute of Cancerology, Bogota 110411; \\ ${ }^{2}$ Department of Chemistry, Faculty of Sciences, National University of Colombia, University City, Bogota 111321; \\ ${ }^{3}$ Department of Urology, National Institute of Cancerology, Bogota 110411; \\ ${ }^{4}$ Department of Urology, National University of Colombia, University City, Bogota 111321; \\ ${ }^{5}$ Department of Pathology, National Institute of Cancerology, Bogota 110411, Colombia
}

Received January 7, 2020; Accepted June 2, 2020

DOI: 10.3892/ol.2021.12637

\begin{abstract}
Prostate cancer (PCa) is characterized as being histologically and molecularly heterogeneous; however, this is not only incorrect among individuals, but also at the multiple foci level, which originates in the prostate gland itself. The reasons for such heterogeneity have not been fully elucidated; however, understanding these may be crucial in determining the course of the disease. $\mathrm{PCa}$ is characterized by a complex network of chromosomal rearrangements, which simultaneously deregulate multiple genes; this could explain the appearance of exclusive events associated with molecular subtypes, which have been extensively investigated to establish clinical management and the development of therapies targeted to this type of cancer. From a clinical aspect, the prognosis of the patient has focused on the characteristics of the index lesion (the largest focus in PCa); however, a significant percentage of patients (11\%) also exhibit an aggressive secondary foci, which may determine the prognosis of the disease, and could be the determining factor of why, in different studies, the classification of the subtypes does not have an association with prognosis. Due to the aforementioned reasons, the analysis of molecular subtypes in several foci, from the same individual could assist in determining the association between clinical evolution and management of patients with PCa. Castration-resistant $\mathrm{PCa}$ (CRPC) has the worst prognosis and develops following androgen ablation therapy. Currently, there are two models to explain the development of CRPC: i) The selection model and ii) the adaptation model; both of which, have been found to
\end{abstract}

Correspondence to: Dr Martha Lucia Serrano, Cancer Biology Research Group, National Institute of Cancerology, Calle 1, 9-85, Bogota 110411, Colombia

E-mail:mlserranol@unal.edu.co

Key words: carcinogenesis, biological tumor markers, gene rearrangement, genetic heterogeneity, prostate neoplasms, castration-resistant prostatic neoplasm, Gleason grading include alterations described in the molecular subtypes, such as Enhancer of zeste 2 polycomb repressive complex 2 subunit overexpression, isocitrate dehydrogenase $\left(\mathrm{NAPD}^{+}\right) 1$ and forkhead box A1 mutations, suggesting that the presence of specific molecular alterations could predict the development of CRPC. This type of analysis could lead to a biological understanding of $\mathrm{PCa}$, to develop personalized medicine strategies, which could improve the response to treatment thus, avoiding the development of resistance. Therefore, the present review discusses the primary molecular factors, to which variable heterogeneity in PCa progress has been attributed.

\section{Contents}

1. Introduction

2. Molecular heterogeneity of PCa

3. Molecular progression to CRPC

4. Conclusions

\section{Introduction}

According to the report by the International Agency for Research on Cancer of 2018 (1), prostate cancer (PCa) has the second highest estimated age-standardized incidence rate worldwide $(29.3$ per 100,000$)$ and is the sixth cause of cancer-associated death in men $(7.6$ per 100,000$)$. The problem with the management of $\mathrm{PCa}$ is due to the difficulty in stratifying between indolent and aggressive cases. Although $<5 \%$ of patients exhibit advanced disease, up to $40 \%$ of patients will eventually develop metastatic disease despite local therapy $(2,3)$. Other patients with PCa undergo hormonal therapy treatment, radical prostatectomy (RP) or radiotherapy, so, numerous cases of $\mathrm{PCa}$ only require expectant management; thus, in these patients, an overtreatment may result in significant morbidity.

High Grade Prostatic Intraepithelial Neoplasia (HGPIN) is a prostate preneoplastic lesion, which may develop towards an invasive $\mathrm{PCa}$ (25 to $30 \%$ ) during a process, which may take over 10 years (4), according to a study conducted at 
Johns Hopkins University School of Medicine, in patients of Baltimore (Maryland, United States of America). Both, HGPIN and PCa are multifocal, and HGPIN foci coexist in adjacent areas of PCa sharing chromosome deletions and interstitial translocations that originate the TMPRSS2-ERG fusion gene and genetic alterations, such as hypermethylation of the $\pi$-class glutathione S-transferase (GSTP1) promoter, which suggests a common origin (5). The heterogeneous and multifocality nature of the disease makes it difficult to understand prostate carcinogenesis (6). Currently, there is no adequate method to differentiate patients with poor prognosis of PCa from those with indolent disease, who should only have a controlled follow-up. The primary method of determining the suitable treatment option for a patient with $\mathrm{PCa}$ is based on the Gleason classification (5), an assessment of its morphological heterogeneity, which is associated with prognosis. Pathologists can classify each focus of PCa using Gleason patterns (GP) ranging from 1 to 5, and assigning a Gleason score (GS); or using the updated Gleason grade group, which includes the two most representative GPs in the tumor $(7,8)$. Despite the association between Gleason classification and tumor behavior (the degree of differentiation of the neoplastic cells) the association between morphological heterogeneity and molecular heterogeneity has not been elucidated (9).

Molecular studies of PCa have revealed numerous recurrent DNA alterations associated with deregulating genes involved in the development of the prostate, such as the deletions and interstitial translocations that originate the TMPRSS2-ERG fusion gene, chromatin modification, cell cycle regulation and androgen signaling $(10,11)$. Over the last decade (12), the investigation into $\mathrm{PCa}$ has focused on identifying the exclusive molecular events in the development of PCa, which could represent early and divergent events and could direct the course of the disease (13); thus, it is crucial to elucidate the carcinogenesis of $\mathrm{PCa}$ and utilize the information in the treatment of patients.

The present review will describe an updated review of intratumoral heterogeneity in multifocal $\mathrm{PCa}$, to understand the carcinogenic process and its implication in the management of the disease; as the vast majority of molecular studies in PCa performed are single focused, and do not take into account molecular heterogeneity, which could contribute to limiting the use of molecular subtypes in the prognosis and treatment of the disease.

\section{Molecular heterogeneity of PCa}

The origin of PCa could be defined by the occurrence of chromosomal rearrangements that simultaneously, and in a coordinated manner, cause the inactivation of tumor suppressor genes (TSG) and the creation of oncogenic fusions, which would support a model of punctuated development in PCa $(11,14)$. This could in turn be associated with the appearance of canonical alterations, and with the molecular subtypes involved in a broad genomic and transcriptomic diversity within and among intraprostatic PCa foci. Several studies have shown potential for their utilization as prognostic biomarker signatures (15-17). Recently published data from The Cancer Genome Atlas (TCGA) (17) supports the division of the major molecular subclasses of localized PCa into erythroblast transformation specific (ETS)-rearrangement $\mathrm{PCa}$ [PCa with rearrangements and overexpression of ETS transcription factor ERG (ERG), ETS variant transcription factor (ETV)-1, -4, or other ETS family transcription factors], SPOP-mutated and CHD1-deleted [speckle type BTB/POZ protein (SPOP)/chromodomain helicase DNA binding protein 1] altered cancers (17), and several smaller categories, such as FOXA1 or IDH1deletion, which have been described in Table I. The use of molecular classifiers to personalize treatment shows promise; however, it is still in its infancy and additional validation and optimization are required to ensure it can be used in a clinical setting.

Multiple complex chromosomal rearrangement, as a cause of molecular alterations in PCa. There are several molecular alterations in the $\mathrm{PCa}$, such as copy number changes, gene fusions, single nucleotide mutations and polymorphisms, methylation, microRNAs and long non-coding RNAs, one of the most characteristic involves multiple complex chromosomal rearrangement processes (Fig. 1A), which has been reported in $63 \%$ of PCa cases (18). These rearrangements can be classified as chromothripsis or chromoplexy (Fig. 1B and C), and some coordinated structured rearrangements may have intermediate chromothripsis and chromoplexy properties (11), for instance both chromothripsis and chromoplexy display random breakage and fusion of genomic segments with low copy numbers, most likely mediated by non-homologous end-joining.

In addition, Dzamba et al (18) used the CouGaR statistical method, in $63 \%$ of $\mathrm{PCa}$, and in $27 \%$ of bladder cancers, which is in contrast with other types of cancer such as rectal, breast and thyroid cancer, where these types of alterations have not been identified. The CouGaR method is a novel method for predicting the overall genomic configuration resulting from characterizing the genomic structure of amplified complex genomic rearrangements, leveraging both depth of coverage (DOC) and discordant pair-end mapping techniques, to identify multiple chromosomal rearrangements. The results of Dzamba et al are noteworthy, as it has been reported that bladder and PCa may both develop in the same patient (19).

It has been found that the breaking points of DNA rearrangements are more likely to occur near specific DNA sequences, where the androgen receptor (AR) binds as a transcription factor, known as androgen response elements (ARE), compared with that in other randomly predicted locations, that is anywhere else in the genome $(20,21)$. This finding suggests that AR-ARE complexes may be predisposed to genomic rearrangements through transcriptional stress, since androgen signaling promotes co-recruitment of androgen receptor and topoisomerase II $\beta$ (TOP $2 \beta$ ) to sites of TMPRSS2-ERG genomic breakpoints, triggering recombinogenic TOP $2 \beta$-mediated DNA double-strand breaks. For example, it has been found that transmembrane serine protease 2 (TMPRSS2)-ERG fusion is induced by the interaction of androgens with AR $(14,22)$.

In the development of $\mathrm{PCa}$, chromothripsis is relatively rare and occurs as one clonal early event; in contrast, chromoplexy is a common and sequential event, which is detected at clonal or sub-clonal level $(14,18,23)$. In a study performed using 57 patients with PCa, Baca et al (11) identified over 5,000 
A

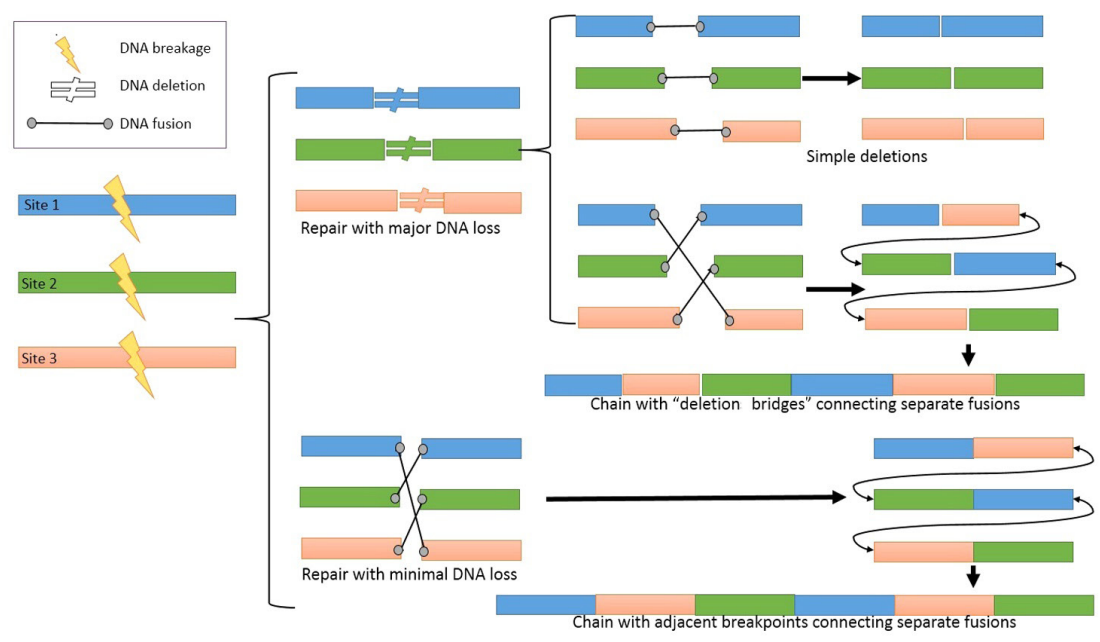

B

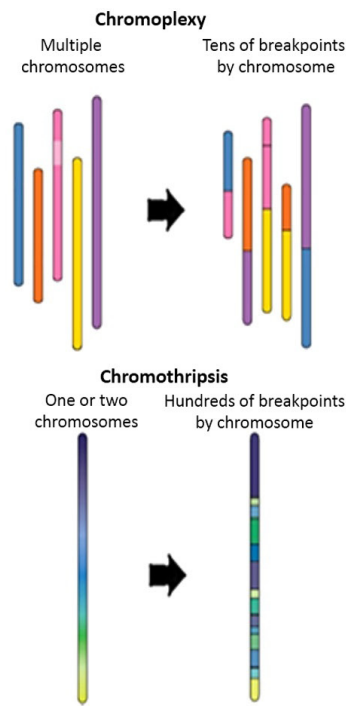

Figure 1. Muliple chromosomal rearrangements in prostate cancer. (A) Mechanisms for the formation of multiple chromosomal rearrangements. DNA ds breaks can be repaired by DNA- breakage, deletion or fusion. Loss of DNA at sites of ds breaks may result in simple deletions (top) or 'deletion bridges' (middle) which span breakpoints from distinct fusions. Adjacent breakpoints or deletion bridges may provide evidence for mulitple rearrangements. Concerted repair with minimal loss of DNA results in fusion breakpoints which map to adjacent positions (indicated by the punctuated arrows). (B) Chromoplexy. Multiple breakpoints, including several chromosomes (C) Chromothripsis. Hundreds of breaking points grouped in one or two chromosomes. DS, double strand.

somatic rearrangements associated with this type of chromosomal rearrangements. Several cancer genes were repeatedly deleted or rearranged by chromoplexy, including PTEN, NK3 homeobox 1, cyclin dependent kinase inhibitor 1B, tumor protein p53 (TP53), and RB transcriptional corepressor 1. These multiple complex chromosomal rearrangements are one of the primary reasons for the high molecular heterogeneity in $\mathrm{PCa}$.

Molecular subtypes in PCa. Over the last decade, several studies have focused on determining the excluding molecular events in the development of PCa, which are able to establish different subtypes, and are associated with the prognosis of the disease, and have the potential to be developed into targeted therapies $(11,16,17,24)$. Therefore, the current status of PCa subtypes, will be subsequently discussed, using TCGA study (17) as a reference for the majority of the comparisons, the prognostic involvement, and the therapies of inhibitors of target oncogenes associated with subtypes, such as EZH2 or ERG (Table I), which have been used or are currently in the experimental phase, in this way some treatments that apply to cases that are $\operatorname{ETS}(+)$ will not work for those that are ETS(-), such as blocking function of ERG regulating co-factors, such as PARP1 (25-27) (Table I). Table I summarizes the main clinical-pathological characteristics of the subtypes and treatments that have been investigated as a development of personalized medicine $(13,17,24-26,28-63)$.

ETS(+) subtypes. The ETS family of transcription factors consists of phosphorylated proteins with DNA-binding domains (ETS domain) that act as either activators or repressors of transcription. The family consists of 30 identified genes, 28 of which are found in the human genome. Previous studies have found that between 50 and $70 \%$ of patients with $\mathrm{PCa}$ overexpress ETS, following gene fusion, which causes ETS to be controlled by ARE (12). Due to the prevalence of these types of rearrangements, efforts to molecularly characterize PCa begin by separating the cases which have gene fusion from those that do not, termed ETS(+) and ETS(-), respectively in numerous studies $(20,38,64)$. TCGA study (17) has characterized four different ETS(+) subtypes, depending on the type of ETS involved in the fusion: ERG, ETV1, ETV4 and Fli-1 proto-oncogene, ETS transcription factor ERG is the most frequently overexpressed ETS. TMPRSS2 the most frequent fusion gene in all ETS fusions; however, fusions with other androgen-regulated genes have also been described, including solute carrier family 45 member 3 and N-myc downstream regulated $1(65)$.

The TMPRSS2-ERG gene fusion causes ERG overexpression, which initiates a cascade of events that continues with Enhancer of zeste 2 polycomb repressive complex 2 subunit (EZH2) overexpression and decreased NKX3-1 expression (Fig. 2) $(20,28)$. EZH2 is a methyltransferase from the polycomb group, involved in tissue-specific differentiation by histone methylation (H3K27), while NKX3-1 is an androgen-regulated, prostate-specific gene, which encodes a critical transcription factor during prostate development by downregulating epithelial cell growth, and is considered a TSG $(20,28,66)$.

Other common molecular alterations in $\mathrm{PCa}$ are deletions and point mutations of PTEN, leading to activation of Akt, which can subsequently lead to over-activation of AR signaling; and in the presence of TMPRSS2-ERG gene fusion, it can increase the activation of a cascade involving ERG, EZH2 and NKX3-1 (Fig. 2) (20,31,33).

ETS(-) subtypes. ETS(-) are PCa subtypes with a canonic alteration, which is different to that in the ETS fusion genes. Whereas rearrangements occurring in ETS(+) tumors display features of chromoplexy, ETS(-) tumors display a higher frequency of chromothripsis (11). Among the ETS(-) subtypes, different studies have found the existence of a highly-expressed EZH2 


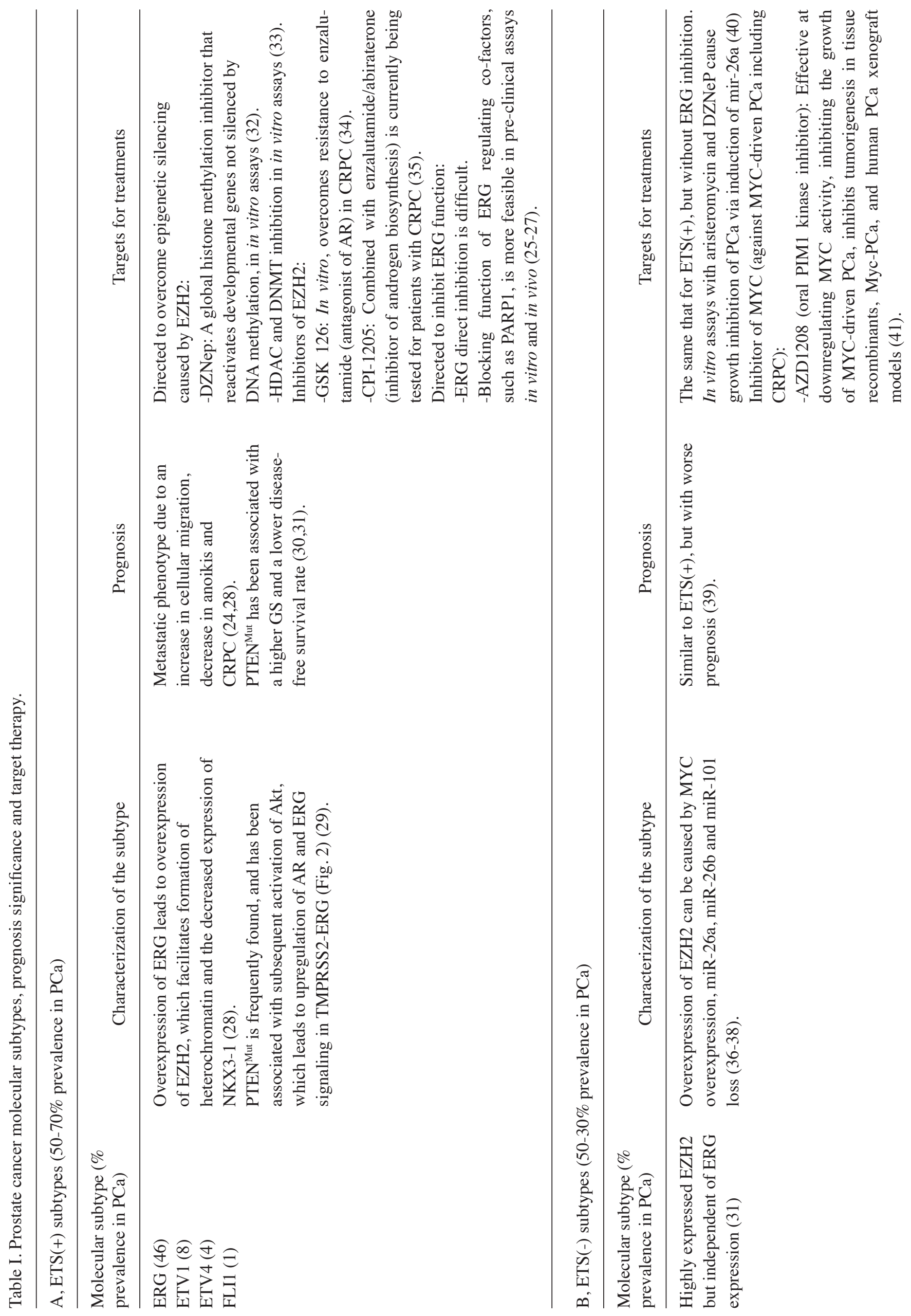




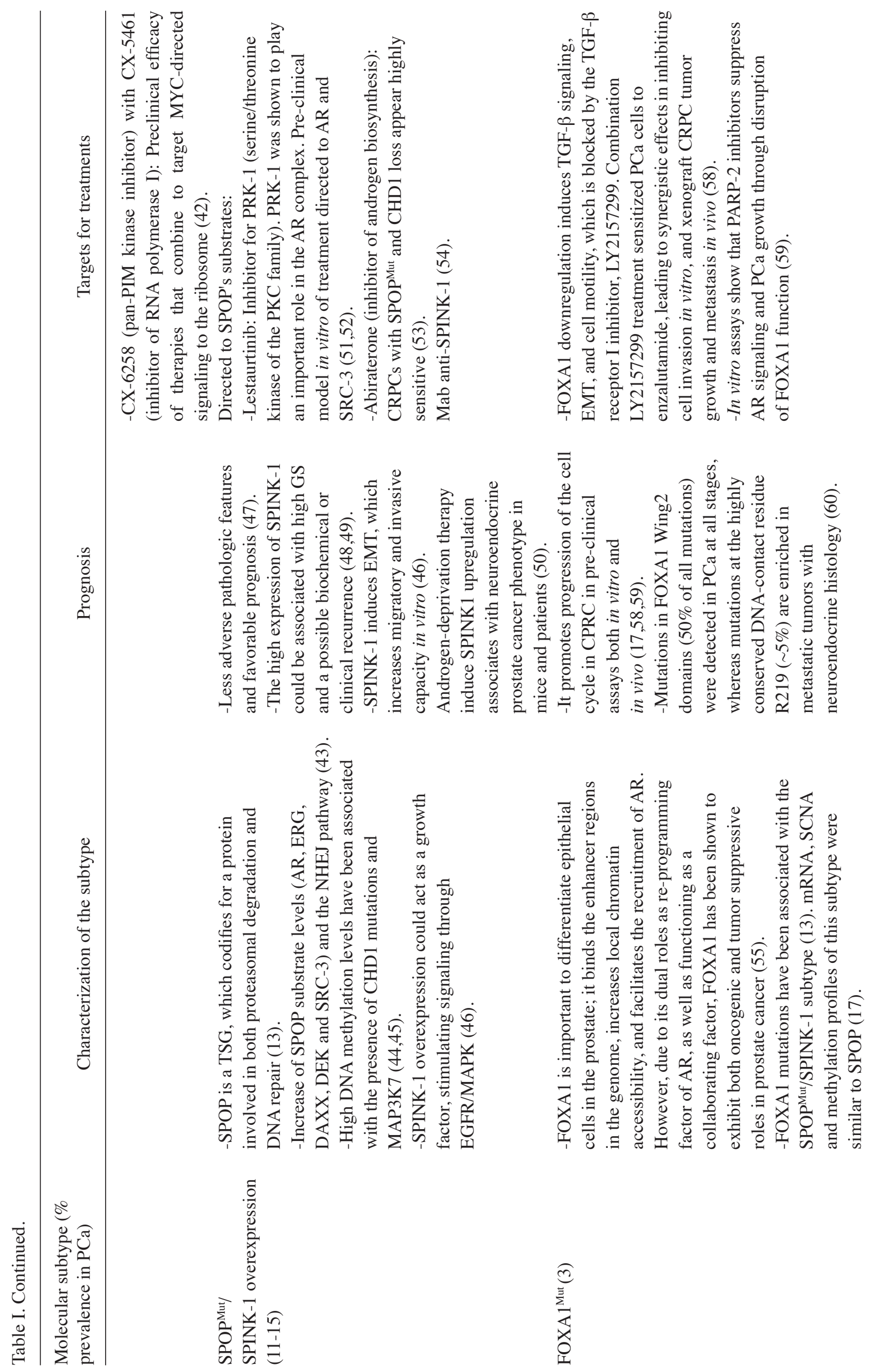




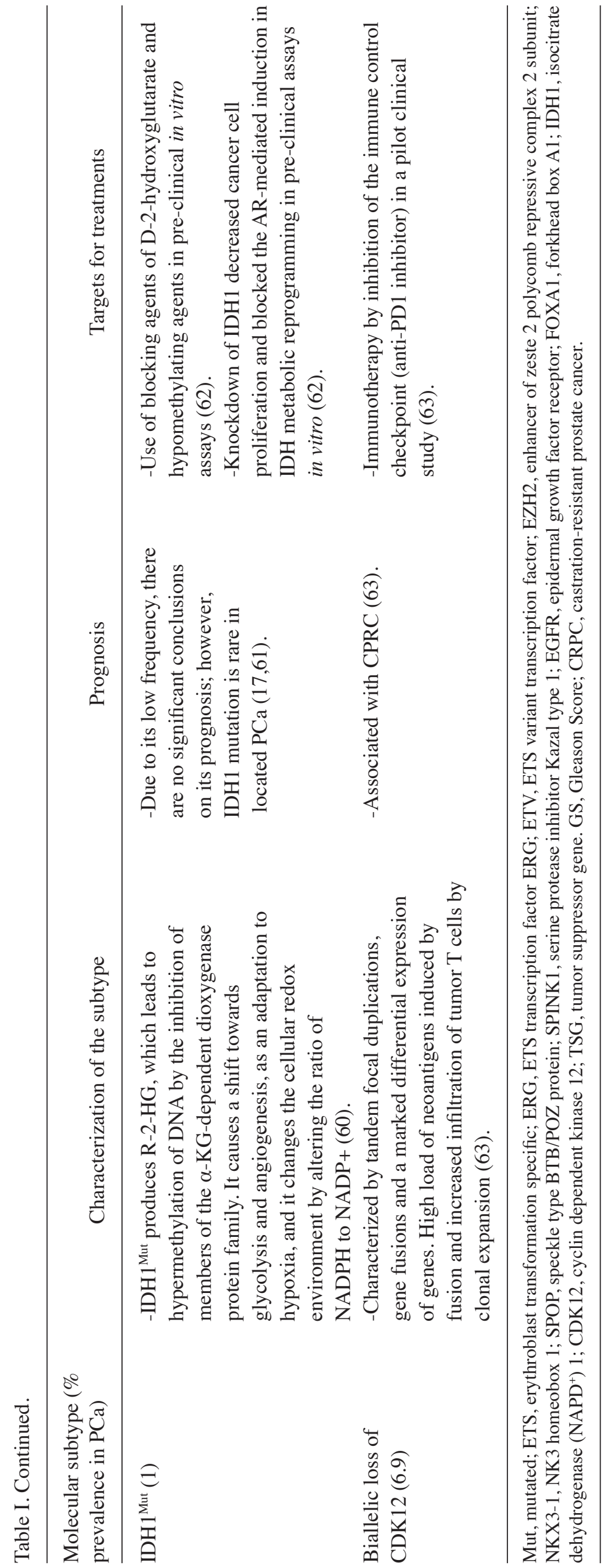




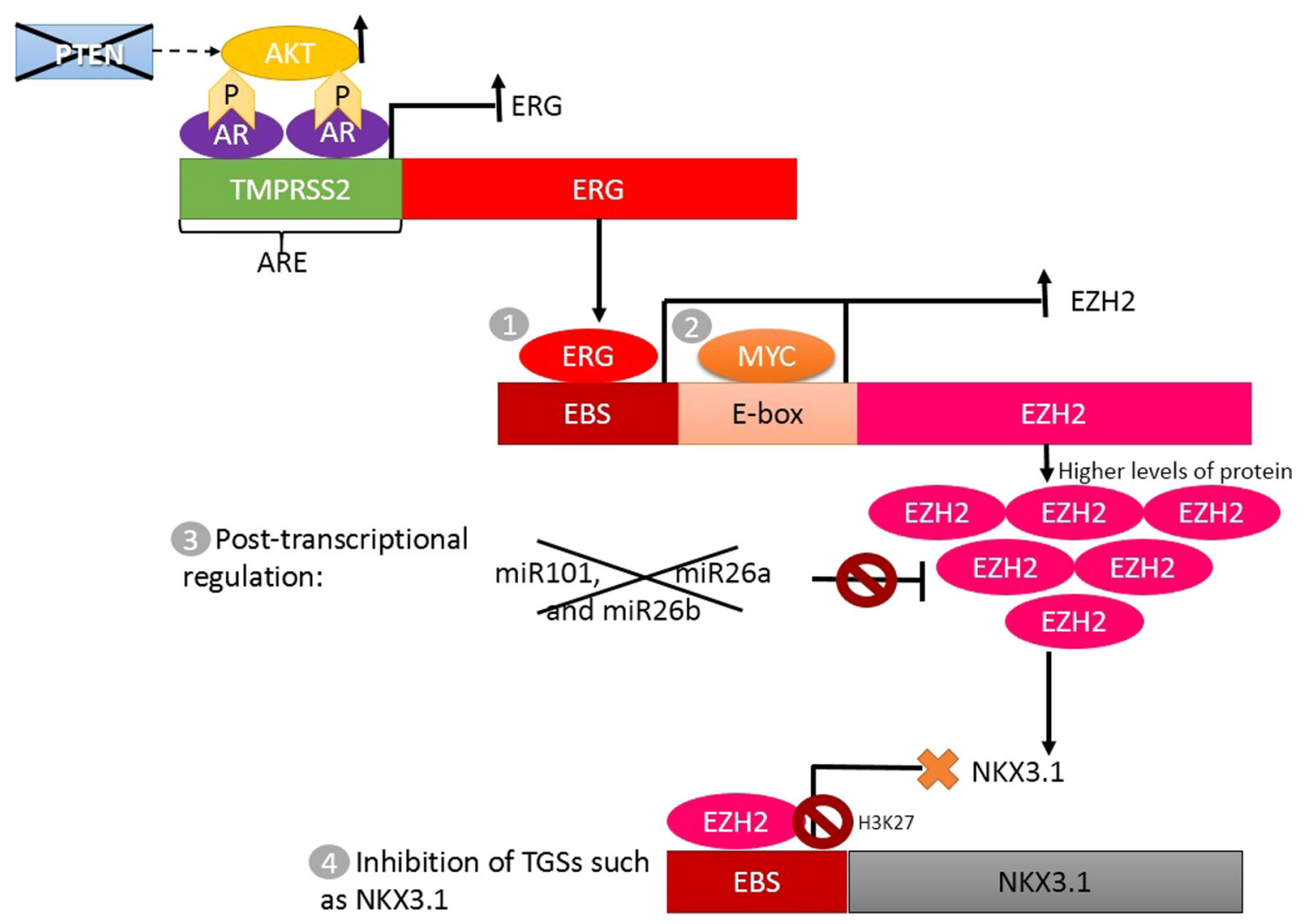

Figure 2. EZH2 overexpression in prostate cancer. The following steps are involved: 1. ERG-dependent mechanisms. Upregulation of the PI3K/Akt signaling pathway by PTEN mutations increases AR signaling and contributes to ERG overexpression in ETS(+) tumors. TMPRSS2-ERG fusion leads to overexpression of ERG, leading to overexpression of the EZH2 protein. 2. MYC oncogene binds to the E-box of the EZH2 promoter and induces its expression. 3. Post-transcriptional regulation of EZH2 by miRNAs. miR101, miR26a and miR26b reduces the translation of EZH2. Genomic loss of miR-101 and overexpression of MYC, which represses the transcription of miR-26a and miR-26b, increases EZH2 translation. 4. EZH2 is involved in gene silencing of TSG, NKX3-1. miR, microRNA; TSG, tumor suppressor gene; EZH2, enhancer of zeste 2 polycomb repressive complex 2 subunit; ERG, ETS transcription factor ERG; AR, androgen receptor; TMPRSS2, transmembrane serine protease 2; EBS, ETS binding site; NKX3-1, NK3 homeobox 1; ARE, androgen response elements.

subtype, which is independent of ERG expression (38,39). The overexpression of EZH2 has been described as well; it is caused by nuclear phosphoprotein MYC, which is involved in the cell cycle progression, apoptosis and cellular transformation. MYC oncogene also represses transcription of microRNA (miR)-26a and $\mathrm{miR}-26 \mathrm{~b}$, which are targets of $\mathrm{EZH} 2$, thus contributing to overexpression of EZH2 $(36,38)$. In addition, the genomic or functional loss of miR-101, a TSG whose targets include the EZH2 gene, causes the overexpression of this gene (37) (Fig. 2).

Since epigenetic abnormalities driven by MYC overexpression have been associated with a poorer prognosis of PCa (progression-free survival after radical prostatectomy), therapies targeting these abnormalities may favor patients with EZH2 overexpression (25-27) (Table I). Furthermore, TCGA describes 3 ETS(-) subtypes, characterized by mutations in genes, including SPOP, overexpression of serine protease inhibitor Kazal type 1 (SPINK1), forkhead box A1 (FOXA1) or isocitrate dehydrogenase (NAPD ${ }^{+} 1$ (IDH1) (17) (Table I). Previous studies have reported an overexpression of SPINK, as an independent subtype $(66,67)$; however, its overexpression was associated with the mutated SPOP subtype in TCGA study (17). In 2018, Wu et al (63) reported a novel subtype, characterized by the inactivation of cyclin dependent kinase 12 , which could benefit from immune checkpoint inhibition therapy (Table I).
In TCGA study, $26 \%$ of PCa cases could not be classified into any of the identified subtypes (17). There were three major groups of prostate cancers in the study, one with mostly unaltered genomes (referred to as quiet), a second group encompassing $50 \%$ of all tumors with an intermediate level of SCNAs, and a third group with a high burden of arm level genomic gains and losses (17). These PCa were clinically and genomically heterogeneous; low-pass and high-pass whole-genome sequencing (WGS) on 100 and 19 tumor/normal pairs, some of had numerous somatic copy number alterations (SCNA) and a high GS, which is an indicator of poor prognosis; $33 \%$ of them were genomically similar to the SPOP and FOXA1 subtypes, others were enriched for mutations of TP53, KDM6A, and KMT2D (lysine methyltransferase 2D) or specific SCNAs spanning MYC and CCND1 (cyclin D1) and other cases had a low GS (GS 6) with fewer genomic alterations (38\% in the 'quiet' class vs. $8 \%$ in the class with the greatest burden of alterations), such as SCNA and DNA methylation patterns similar to those in normal tissue (17).

Table I organizes the different subtypes with their clinical significance and the treatment options that are being addressed for the future development of personalized medicine; however, this classification has not been clear or reproducible in numerous cases, nor has the response of patients to the treatments either, as $\sim 75 \%$ of PCa are multifocal, and more than 


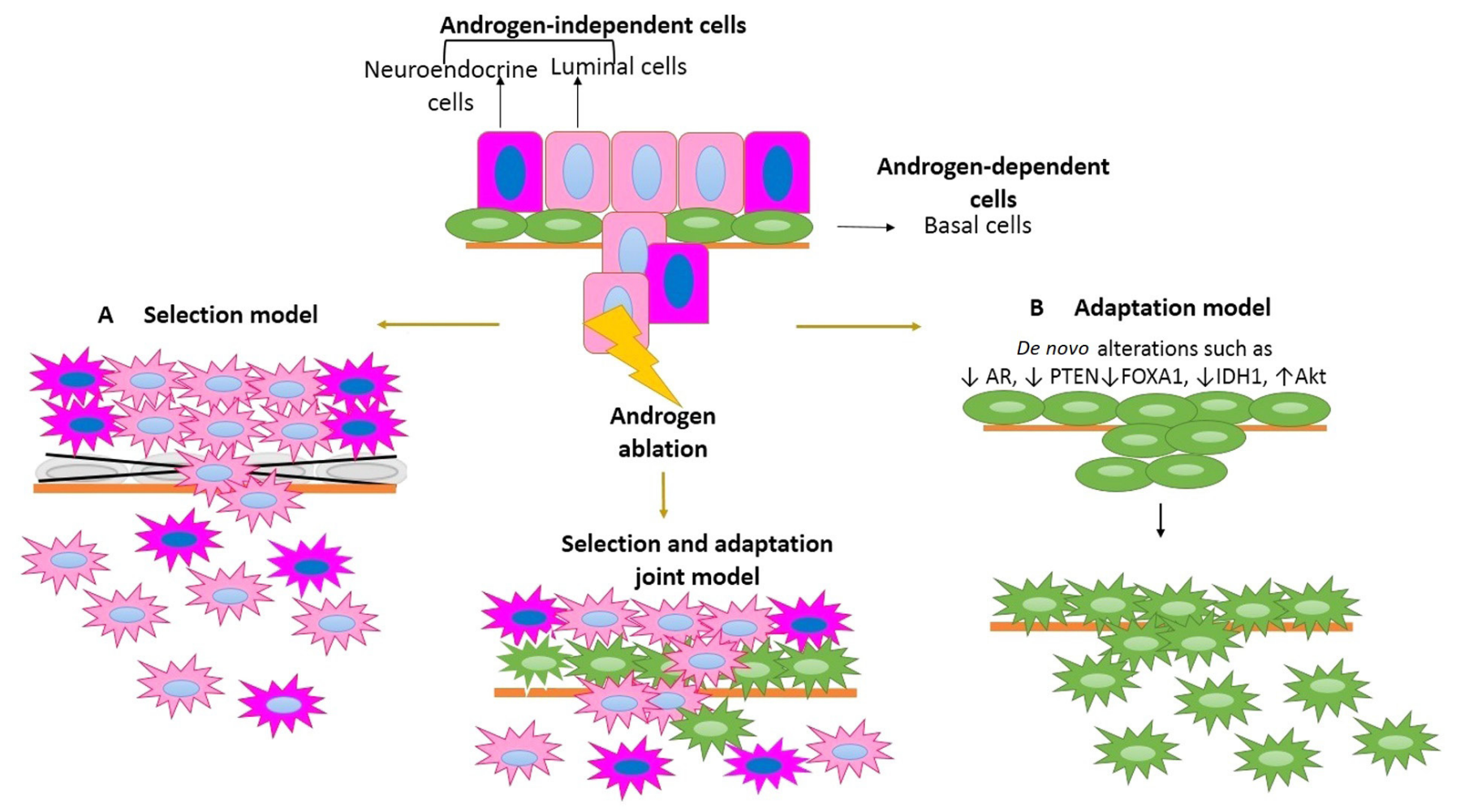

Figure 3. Models proposed for the origin of castration resistant PCa. (A) Selection model. Most luminal cells undergo apoptosis, following androgen ablation, while basal cells proliferate and neuroendocrine cells are resistant to castration. (B) Adaptation model. Following androgen ablation, androgen-dependent PCa cells acquire novel alterations which allow them become androgen-independent. However, it is also possible that both models, independently or cooperatively, contribute to CRPC growth in a patient, forming a selection and adaptation joint model. The orange line indicates the basal membrane. The grey cells with a black X represent cells that have undergone apoptosis. AR, androgen receptor; IDH1, isocitrate dehydrogenase (NAPD $) 1$; $\mathrm{PCa}$, prostate cancer.

one subtypes can coexist in the same patient with multifocal PCa $(6,68)$.

Intratumoral molecular heterogeneity. The Gleason classification, using histological methods, that heterogeneity in multifocal PCa can be recognized, which is higher when analyzed from a molecular point of view $(6,69)$. This intratumoral heterogeneity makes it difficult to associate specific molecular alterations, detected in a single focus, with the clinical behavior of a patient with multifocal PCa $(6,69)$. In molecular studies, the pattern of the index tumor is typically obtained to assign molecular alterations and subtypes; however, other foci are not taken into account (6). The index tumor is the largest tumor focus, which in most cases $(89 \%)$ can be associated with significant pathological parameters, such as the highest GS, the largest tumor volume and extraprostatic extension (70); however, this is not always the case (69). Numerous studies have found that a single clone is responsible for the dispersal of all metastatic foci $(13,71,72)$; which suggests that identifying the 'deadly' clone is of utmost importance, and should not necessarily start from the index tumor.

Due to the heterogeneity caused by multifocality in PCa, it is necessary to perform studies, that analyze the molecular alterations in various foci, which would allow the identification of the impact of different molecular subtypes in the same patient $(4,64)$. Some studies using the TMPRSS2-ERG fusion (73,74), PTEN deletion (75), SPINK1, ERG (67), and whole genome sequencing $(6,75-77)$ have found a markedly interfocal discordance, which was consistent with the concept that multiple foci of PCa have a multiclonal origins (6). Wei et al (6) also found this heterogeneity when using commercial PCa diagnostic kits (Decipher, Prolaris and Oncotype DX), which are based on the expression of various genes, including immune response genes like testis-specific basic protein and PBX homeobox 1 of Decipher, cell cycle-related genes CDC20 (Cell Division Cycle 2), CDKN3 (Cyclin Dependent Kinase Inhibitor 3), CDC2 (cell division control protein 2 homolog) of Prolaris, genes of androgen signaling AZGP1 (Alpha-2-Glycoprotein 1) and FAM13C (Family With Sequence Similarity 13 Member C) of Oncotype DX. These results suggest that applying a single subtype of the molecular taxonomy of PCa proposed by TCGA to a patient, i.e., studying a single focus, is an over simplified and incorrect view of the molecular landscape of PCa.

\section{Molecular progression to castrate-resistant prostate cancer}

As aforementioned, the origins of $\mathrm{PCa}$ begins as a pre-neoplastic lesion which progresses to localized cancer, and can subsequently metastasize. Elimination of androgens using surgical or chemical castration, in numerous cases, results in control of PCa $(78,79)$. However, when relapse occurs despite treatment, $\mathrm{PCa}$ has progressed to an androgen-independent form of cancer or CRPC, which is considered the most aggressive form of PCa (80). 
Most of the molecular alterations in $\mathrm{PCa}$ have been described from HGPIN (or associated with HGPIN). However, there are studies, which have found associations between some of these alterations with different stages of PCa progression. ETS fusions and FOXA1 mutations frequently occur in HGPIN $(14,23)$. Overexpression of SPINK1 $(\sim 10-25 \%)$ and SPOP ( 11\%), TP53 ( 25\%), IDH1 ( 1\%), MAP3K7 and CHD1 $(\sim 10-20 \%)$ mutations $(11,13,17,23,49,81)$ are more frequent in localized PCa, while the highest and lowest expression levels of EZH2 and NKX3-1, respectively, together with PTEN deletion, have been found in metastatic CRPC $(11,23,82)$. Monoallelic loss of PTEN is present in up to $60 \%$ of localized prostate cancers and complete loss of PTEN in prostate cancer is linked to metastasis and androgen-independent progression (86). Alteration of the AR signaling pathway compared with that in other pathways in CRPC suggest that AR signaling continues being the 'master regulator' for $\mathrm{PCa}$ progression $(45,55,84)$, including AR copy number gain $(24 \%$ of CRPCs) or AR point mutation (20\% of CRPCs). These results assist to define the sequence of the molecular events in the development of $\mathrm{PCa}$, from the origins of the disease through to its progression into metastasis, resistance to treatment and death.

There are 3 types of cells which interact in PCa to survive androgen ablation treatment: Androgen-dependent, androgen producing, and androgen-independent cells (85). The interaction among them determines whether CRPC will develop or not. The pathway which leads from the development of androgen-dependent to androgen-independent cells is still unknown. However, there are two models which have been used to explain this process. Some studies suggest that there is a collection of androgen-independent preexisting cells following therapy (selection model) $(86,87)$; in contrast, other studies postulate that cells acquire novel alterations which allow them to survive in the absence of androgens (adaptation model) (88) for developing CRPC (Fig. 3).

Selection model. In this model, primary PCa consists of a heterogeneous mix of luminal, neuroendocrine and stem cells. When the patient undergoes androgen ablation treatment, most of the androgen-dependent cells undergo apoptosis, while androgen-independent cells persist and survive due to their low androgen requirement (Fig. 3) (86,87,89).

The vast majority of $\mathrm{PCa}$ are luminally differentiated adenocarcinomas with the presence of neuroendocrine cells, and respond to hormonal therapy (90); however, there are some tumors, which consist of aggressive and highly proliferating neuroendocrine cells only, for example small cell neuroendocrine $\mathrm{PCa}$, which do not respond to hormone therapy, therefore platinum-based chemotherapy (phase II trial) is used $(90,91)$. These malignant neuroendocrine cells, which share their origin with normal prostatic neuroendocrine cells (93), express epidermal growth factor receptor (EGFR) and receptor tyrosine-protein kinase erbB-2; for these reasons, they are classified as androgen-independent cells (94), and their abundance is considered a promising prognostic marker for the development of CRPC (95).

A previous study compared global transcriptomic profiles of normal basal and luminal epithelial lineages from samples of patients with PCa and PCa cell lines (87). It was found that
PCa cells exhibited a gene expression profile similar to that found in a luminal cell and aggressive and neuroendocrine PCa were similar to basal cells (87).

In addition to cell type, in a few cases, point mutations in AR can cause cells, which were originally androgen-dependent, to become androgen-independent cells, and can be resistant to therapy, that is, those pre-existing mutations in the localized disease confer a selective advantage with threapy-resistant cells $(84,95-97)$. The S646F mutation within $\mathrm{AR}$, in the hinge region, has been associated with a short response to endocrine therapy, due to a markedly increased transcriptional activity on ARE-containing promoters (95). In addition, AR gene copies (two to four copies), due to polysomy of the X-chromosome, are present in a subgroup of localized PCa, and these specimens may have an advantage in low concentrations of androgens due to therapy (96), since the additional AR copies may be a factor leading to a poor clinical outcome of antiandrogen therapy as there is a compensatory mechanism allowing activation of the AR post-castration. Furthermore, that study concluded that high stage primary prostate cancer may be associated with increased frequencies of aneuploidies of the $\mathrm{X}$ chromosome resulting in an increased AR gene copies number.

Adaptation model. The adaptation model suggests that resistance to castration is the result of the acquisition of genetic and/or epigenetic alterations in response to therapy, which allows cells that were previously dependent on androgens to proliferate at low concentrations of androgens due to therapy (97). Adaptations to androgen ablation treatment include the occurrence of mutations with a copy number gain of the AR gene, changes in the expression of AR co-regulation molecules $(48,84,98)$, and deregulation of key molecules in proliferation (99), such as Akt overexpression (29).

The evidence supports the selection model (100-102); however, it is difficult to establish either of these models as the definitive or exclusive mechanism. It is also possible that both models independently or cooperatively contribute to the development of CRPC $(85,100)$. Some cells could be independent of androgens and be selected, or they can also gain adaptive advantages to proliferate at low concentrations of androgens; or there could be cells selected for their independence from androgens, and others that adapt and proliferate at low concentrations of androgens (100).

The aforementioned neuroendocrine PCa from small cells may arise de novo, which would support the selection model; however, these generally occur as recurrent tumors in men who have received hormone therapy for prostatic adenocarcinoma, suggesting that the neuroendocrine phenotype is driven by the hostile environment created by hormone therapy, or the adaptation model, and such tumors are composed of pure neuroendocrine cells that are highly proliferative and aggressive $(88,90,103)$, due mutation in P53 (104) (allele of a missense transition converting $\mathrm{G}$ to $\mathrm{A}$ at position 747 , changing negatively charged aspartic acid to hydrophilic amino acid asparagine at amino acid 184) and the inactivation of the interleukin-8-C-X-C motif chemokine receptor 2 signaling pathway $(90,104)$. Differential epigenetic markers between the neuroendocrine and non-neuroendocrine CRPC 
support a key role of the epigenome in the emergence and/or maintenance of neuroendocrine CRPC (105).

With the widespread use of novel drugs targeting the androgenic axis, such as abiraterone acetate and enzalutamide, there has been a rapid increase in the incidence of small cell neuroendocrine carcinoma $(91,105)$, on the basis of autopsy series and other studies this type of $\mathrm{PCa}$ may represent approximately $25 \%$ of late stage of PCa (106), which will become a major challenge in the treatment of these patients. The clarification of the determining factors that lead to CRPC will be key to understanding the carcinogenesis process and guiding the clinical management of each patient.

\section{Conclusions}

The use of molecular subtypes in PCa to personalize treatment is promising; however, it is necessary to consider multifocality. The lack of an association between subtype and prognosis in PCa may be due to the fact that only the index tumor is investigated. It is important to analyze the subtypes in multiple foci, to elucidate the development of $\mathrm{PCa}$, which could include different molecular subtypes; during the development of tumor foci, these would be selected according to their adaptive advantages, such as resistance to castration and the ability to metastasize.

The presence or absence of a specific alteration in any of the foci may be associated with the potential of PCa to progress to CRPC or to be the target for the development of targeted therapy, which does not necessarily have to be found in the index lesion.

\section{Acknowledgements}

Not applicable.

\section{Funding}

The present study was funded by the National Institute of Cancerology of Bogota, Colombia (grant no. C190103001-09).

\section{Availability of data and materials}

Data sharing is not applicable to this article, as no datasets were generated or analyzed during the current study.

\section{Authors' contributions}

YYSM and MLS were responsible for writing the manuscript, editing, acquisition, analysis, interpretation of the data, contributed to data acquisition and edited references. YYSM, MCSS, $\mathrm{RV}, \mathrm{JAM}$ and MLS contributed to the conception and design of the article and were involved in critical revision of the manuscript. All authors read and approved the final manuscript.

\section{Ethics approval and consent to participate}

Not applicable.

\section{Patient consent for publication}

Not applicable.

\section{Competing interests}

The authors declare that they have no competing interests.

\section{References}

1. IARC: Global Cancer Observatory https://gco.iarc.fr/today/home: GLOBOCAN; 2018 The Global Cancer Observatory (GCO) is an interactive web-based platform presenting global cancer statistics to inform cancer control and research.

2. Beltran H, Yelensky R, Frampton GM, Park K, Downing SR, MacDonald TY, Jarosz M, Lipson D, Tagawa ST, Nanus DM, et al: Targeted next-generation sequencing of advanced prostate cancer identifies potential therapeutic targets and disease heterogeneity. Eur Urol 63: 920-926, 2013.

3. Lu-Yao G, Albertsen PC, Stanford JL, Stukel TA, Walker-Corkery E and Barry MJ: Screening, treatment, and prostate cancer mortality in the Seattle area and Connecticut: Fifteen-year follow-up. J Gen Intern Med 23: 1809-1814, 2008.

4. Partin AW: High-grade prostatic intraepithelial neoplasia on a prostate biopsy-what does it mean? Rev Urol 4: 157-158, 2002.

5. De Marzo AM, Marchi VL, Epstein JI and Nelson WG: Proliferative inflammatory atrophy of the prostate: Implications for prostatic carcinogenesis. Am J Pathol 155: 1985-1992, 1999.

6. Wei L, Wang J, Lampert E, Schlanger S, DePriest AD, Hu Q, Gomez EC, Murakam M, Glenn ST, Conroy J, et al: Intratumoral and intertumoral genomic heterogeneity of multifocal localized prostate cancer impacts molecular classifications and genomic prognosticators. Eur Urol 71: 183-192, 2017.

7. Epstein JI, Allsbrook WC, Amin MB and Egevad LL; ISUP Grading Committee: The 2005 International society of urological pathology (ISUP) consensus conference on gleason grading of prostatic carcinoma. Am J Surg Pathol 29: 1228-1242, 2005.

8. Epstein JI, Egevad L, Amin MB, Delahunt B, Srigley JR and Humphrey PA; Grading Committee: The 2014 International Society of Urological Pathology (ISUP) Consensus Conference on Gleason Grading of Prostatic Carcinoma: Definition of Grading Patterns and Proposal for a New Grading System. Am J Surg Pathol 40: 244-252, 2016.

9. De Nunzio C, Pastore AL, Lombardo R, Simone G, Leonardo C, Mastroianni R, Collura D, Muto G, Gallucci M, Carbone A, et al: The new Epstein gleason score classification significantly reduces upgrading in prostate cancer patients. Eur J Surg Oncol 44: 835-839, 2018.

10. Baca SC and Garraway LA: The genomic landscape of prostate cancer. Front Endocrinol (Lausanne) 3: 69, 2012.

11. Baca SC, Prandi D, Lawrence MS, Mosquera JM, Romanel A, Drier Y, Park K, Kitabayashi N, MacDonald TY, Ghandi M, et al: Punctuated evolution of prostate cancer genomes. Cell 153: 666-677, 2013.

12. Tomlins SA, Rhodes DR, Perner S, Dhanasekaran SM, Mehra R, Sun XW, Varambally S, Cao X, Tchinda J, Kuefer R, et al: Recurrent fusion of TMPRSS2 and ETS transcription factor genes in prostate cancer. Science 310: 644-648, 2005.

13. Barbieri CE, Baca SC, Lawrence MS, Demichelis F, Blattner M, Theurillat JP, White TA, Stojanov P, Van Allen E, Stransky N, et al: Exome sequencing identifies recurrent SPOP, FOXA1 and MED12 mutations in prostate cancer. Nat Genet 44: 685-689, 2012.

14. Berger MF, Lawrence MS, Demichelis F, Drier Y, Cibulskis K, Sivachenko AY, Sboner A, Esgueva R, Pflueger D, Sougnez C, et al: The genomic complexity of primary human prostate cancer. Nature 470: 214-220, 2011.

15. Tomlins SA, Laxman B, Dhanasekaran SM, Helgeson BE, Cao X, Morris DS, Menon A, Jing X, Cao Q, Han B, et al: Distinct classes of chromosomal rearrangements create oncogenic ETS gene fusions in prostate cancer. Nature 448: 595-599, 2007.

16. Tomlins SA, Alshalalfa M, Davicioni E, Erho N, Yousefi K, Zhao S, Haddad Z, Den RB, Dicker AP, Trock BJ, et al: Characterization of 1577 primary prostate cancers reveals novel biological and clinicopathologic insights into molecular subtypes. Eur Urol 68: 555-567, 2015.

17. Cancer Genome Atlas Research Network: The Molecular Taxonomy of Primary Prostate Cancer. Cell 163: 1011-1025, 2015.

18. Dzamba M, Ramani AK, Buczkowicz P, Jiang Y, Yu M, Hawkins $\mathrm{C}$ and Brudno M: Identification of complex genomic rearrangements in cancers using CouGaR. Genome Res 27: 107-117, 2017.

19. Chun TY: Coincidence of bladder and prostate cancer. J Urol 157: 65-67, 1997. 
20. Yu J, Mani RS, Cao Q, Brenner CJ, Cao X, Wang X, Wu L, Li J, $\mathrm{Hu}$ M, Gong Y, et al: An integrated network of androgen receptor, polycomb, and TMPRSS2-ERG gene fusions in prostate cancer progression. Cancer Cell 17: 443-454, 2010.

21. Lin C, Yang L, Tanasa B, Hutt K, Ju BG, Ohgi K, Zhang J, Rose DW, Fu XD, Glass CK and Rosenfeld MG: Nuclear receptor-induced chromosomal proximity and DNA breaks underlie specific translocations in cancer. Cell 139: 1069-1083, 2009.

22. Mani RS, Tomlins SA, Callahan K, Ghosh A, Nyati MK, Varambally S, Palanisamy $\mathrm{N}$ and Chinnaiyan AM: Induced chromosomal proximity and gene fusions in prostate cancer. Science 326: 1230, 2009.

23. Jung SH, Shin S, Kim MS, Baek IP, Lee JY, Lee SH, Kim TM, Lee SH and Chung YJ: Genetic progression of high grade prostatic intraepithelial neoplasia to prostate cancer. Eur Urol 69: 823-830, 2016

24. Lapointe J,Li C, Higgins JP, van de Rijn M, Bair E, Montgomery K, Ferrari M, Egevad L, Rayford W, Bergerheim U, et al: Gene expression profiling identifies clinically relevant subtypes of prostate cancer. Proc Natl Acad Sci USA 101: 811-816, 2004.

25. Brenner JC, Ateeq B, Li Y, Yocum AK, Cao Q, Asangani IA, Patel S, Wang X, Liang $\mathrm{H}$, Yu J, et al: Mechanistic rationale for inhibition of poly(ADP-ribose) polymerase in ETS gene fusion-positive prostate cancer. Cancer Cell 19: 664-678, 2011

26. Williamson SR and Cheng L: Potential for targeted therapy in prostate cancers with ERG abnormalities. Asian J Androl 13: 781-782, 2011.

27. Karpova Y, Wu C, Divan A, McDonnell ME, Hewlett E, Makhov P, Gordon J, Ye M, Reitz AB, Childers WE, et al: Non-NAD-like PARP-1 inhibitors in prostate cancer treatment. Biochem Pharmacol 167: 149-162, 2019.

28. Kunderfranco P, Mello-Grand M, Cangemi R, Pellini S, Mensah A, Albertini V, Malek A, Chiorino G, Catapano CV and Carbone GM: ETS transcription factors control transcription of EZH2 and epigenetic silencing of the tumor suppressor gene Nkx3.1 in prostate cancer. PLoS One 5: e10547, 2010.

29. Wang S, Gao J,Lei Q, Rozengurt N,Pritchard C,Jiao J, Thomas GV, Li G, Roy-Burman P, Nelson PS, et al: Prostate-specific deletion of the murine Pten tumor suppressor gene leads to metastatic prostate cancer. Cancer Cell 4: 209-221, 2003

30. Gao T, Mei Y, Sun H, Nie Z, Liu X and Wang S: The association of Phosphatase and tensin homolog (PTEN) deletion and prostate cancer risk: A meta-analysis. Biomed Pharmacother 83: 114-121, 2016.

31. Leinonen KA, Saramäki OR, Furusato B, Kimura T, Takahashi H, Egawa S, Suzuki H, Keiger K, Ho Hahm S, Isaacs WB, et al: Loss of PTEN is associated with aggressive behavior in ERG-positive prostate cancer. Cancer Epidemiol Biomarkers Prev 22: 2333-2344, 2013

32. Ngollo M, Lebert A, Dagdemir A, Judes G, Karsli-Ceppioglu S, Daures M, Kemeny JL, Penault-Llorca F, Boiteux JP, Bignon YJ, et al: The association between histone 3 lysine 27 trimethylation ( $\mathrm{H} 3 \mathrm{~K} 27 \mathrm{me} 3)$ and prostate cancer: Relationship with clinicopathological parameters. BMC Cancer 14: 994, 2014

33. Ishigami-Yuasa M,Ekimoto $\mathrm{H}$ and Kagechika $\mathrm{H}$ : Class IIb HDAC inhibition enhances the inhibitory effect of Am80, a synthetic retinoid, in prostate cancer. Biol Pharm Bull 42: 448-452, 2019.

34. Bai Y, Zhang Z, Cheng L, Wang R, Chen X, Kong Y, Feng F, Ahmad N, Li L and Liu X: Inhibition of enhancer of zeste homolog 2 (EZH2) overcomes enzalutamide resistance in castration-resistant prostate cancer. J Biol Chem 294: 9911-9923, 2019.

35. Taplin ME, Hussain A, Shah S, Neal D. Shore, Manish Agrawal, William Clark, et al: ProSTAR: A phase Ib/II study of CPI-1205, a small molecule inhibitor of EZH2, combined with enzalutamide (E) or abiraterone/prednisone $(\mathrm{A} / \mathrm{P})$ in patients with metastatic castration-resistant prostate cancer (mCRPC). J Clin Oncol, 2019.

36. Koh CM, Iwata T, Zheng Q, Bethel C, Yegnasubramanian S and De Marzo AM: Myc enforces overexpression of EZH2 in early prostatic neoplasia via transcriptional and post-transcriptional mechanisms. Oncotarget 2: 669-683, 2011.

37. Varambally S, Cao Q, Mani RS, Shankar S, Wang X, Ateeq B, Laxman B, Cao X, Jing X, Ramnarayanan K, et al: Genomic loss of microRNA-101 leads to overexpression of histone methyltransferase EZH2 in cancer. Science 322: 1695-699, 2008.

38. Börno ST, Fischer A, Kerick M, Fälth M, Laible M, Brase JC, Kuner R, Dahl A, Grimm C, Sayanjali B, et al: Genome-wide DNA methylation events in TMPRSS2-ERG fusion-negative prostate cancers implicate an EZH2-dependent mechanism with miR-26a hypermethylation. Cancer Discov 2: 1024-1035, 2012.
39. Melling N, Thomsen E, Tsourlakis MC, Kluth M, Hube-Magg C, Minner S, Koop C, Graefen M, Heinzer H, Wittmer C, et al: Overexpression of enhancer of zeste homolog 2 (EZH2) characterizes an aggressive subset of prostate cancers and predicts patient prognosis independently from pre- and postoperatively assessed clinicopathological parameters. Carcinogenesis 36 : $1333-1340,2015$

40. Uchiyama N, Tanaka Y and Kawamoto T: Aristeromycin and DZNeP cause growth inhibition of prostate cancer via induction of mir-26a. Eur J Pharmacol 812: 138-146, 2017.

41. Kirschner AN, Wang J, van der Meer R, Anderson PD, Franco-Coronel OE, Kushner MH, Everett JH, Hameed O, Keeton EK, Ahdesmaki M, et al: PIM kinase inhibitor AZD1208 for treatment of MYC-driven prostate cancer. J Natl Cancer Inst 107: dju407, 2015

42. Rebello RJ, Kusnadi E, Cameron DP, Pearson HB, Lesmana A, Devlin JR, Drygin D, Clark AK, Porter L, Pedersen J, et al: The dual inhibition of RNA Pol I transcription and PIM kinase as a new therapeutic approach to treat advanced prostate cancer. Clin Cancer Res 22: 5539-5552, 2016.

43. Boysen G, Barbieri CE, Prandi D, Blattner M, Chae SS, Dahija A, Nataraj S, Huang D, Marotz C, Xu L, et al: SPOP mutation leads to genomic instability in prostate cancer. Elife 4: e09207, 2015.

44. Rodrigues LU, Rider L, Nieto C, Romero L, Karimpour-Fard A, Loda M, Lucia MS, Wu M, Shi L, Cimic A, et al: Coordinate loss of MAP3K7 and CHD1 promotes aggressive prostate cancer. Cancer Res 75: 1021-1034, 2015.

45. Grasso CS, Wu YM, Robinson DR, Cao X, Dhanasekaran SM, Khan AP, Quist MJ, Jing X, Lonigro RJ, Brenner JC, et al: The mutational landscape of lethal castration-resistant prostate cancer. Nature 487: 239-243, 2012

46. Shen C, Zhang J, Qi M, Chang YWY and BH: Roles of serine protease inhibitor kazal type 1 (SPINK1) in prostate cancer. Med chem 4: 725-728, 2014.

47. Liu D, Takhar M, Alshalalfa M, Erho N, Shoag J, Jenkins RB, Karnes RJ, Ross AE, Schaeffer EM, Rubin MA, et al: Impact of the SPOP mutant subtype on the interpretation of clinical parameters in prostate cancer. JCO Precis Oncol 2018: 10, 2018.

48. Johnson MH, Ross AE, Alshalalfa M, Erho N, Yousefi K, Glavaris S, Fedor H, Han M, Faraj SF, Bezerra SM, et al: SPINK1 Defines a molecular subtype of prostate cancer in men with more rapid progression in an at risk, natural history radical prostatectomy cohort. J Urol 196: 1436-1444, 2016.

49. Yun SJ, Kim SK, Kim J, Cha EJ, Kim JS, Kim SJ, Ha YS, Kim YH, Jeong P, Kang HW, et al: Transcriptomic features of primary prostate cancer and their prognostic relevance to castration-resistant prostate cancer. Oncotarget 8: 114845-114855, 2017.

50. Tiwari R, Manzar N, Bhatia V, Yadav A, Nengroo MA, Datta D, Carskadon S, Gupta N, Sigouros M, Khani F, et al: Androgen deprivation upregulates SPINK1 expression and potentiates cellular plasticity in prostate cancer. Nat Commun 11:384, 2020

51. Geng C, Rajapakshe K, Shah SS, Shou J, Eedunuri VK, Foley C, Fiskus W, Rajendran M, Chew SA, Zimmermann M, et al: Androgen receptor is the key transcriptional mediator of the tumor suppressor SPOP in prostate cancer. Cancer Res 74 5631-5643, 2014.

52. Lu D, Lee J, Lee A and Lee R: Development of a new approach for the therapy of prostate cancer with SPOP mutations. J Cancer Therapy 6: 841-848, 2015.

53. Boysen G, Rodrigues DN, Rescigno P, Seed G, Dolling D, Riisnaes R, Crespo M, Zafeiriou Z, Sumanasuriya S, Bianchini D, et al: SPOP-Mutated/CHD1-deleted lethal prostate cancer and abiraterone sensitivity. Clin Cancer Res 24: 5585-5593, 2018

54. Ateeq B, Tomlins SA, Laxman B, Asangani IA, Cao Q, Cao X, Li Y, Wang X, Feng FY, Pienta KJ, et al: Therapeutic targeting of SPINK1-positive prostate cancer. Sci Transl Med 3: 72ra17, 2011.

55. Stelloo S, Nevedomskaya E, Kim Y, Schuurman K, Valle-Encinas E, Lobo J, Krijgsman O, Peeper DS, Chang SL, Feng FY, et al: Integrative epigenetic taxonomy of primary prostate cancer. Nat Commun 9: 4900, 2018.

56. Imamura Y, Sakamoto S, Endo T, Utsumi T, Fuse M, Suyama T, Kawamura K, Imamoto T, Yano K, Uzawa K, et al: FOXA1 promotes tumor progression in prostate cancer via the insulin-like growth factor binding protein 3 pathway. PLoS One 7: e42456, 2012.

57. Adams EJ, Karthaus WR, Hoover E, Liu D, Gruet A, Zhang Z, Cho H, DiLoreto R, Chhangawala S, Liu Y, et al: FOXA1 mutations alter pioneering activity, differentiation and prostate cancer phenotypes. Nature 571: 408-412, 2019. 
58. Song B, Park SH, Zhao JC, Fong KW, Li S, Lee Y, Yang YA Sridhar S,Lu X, Abdulkadir SA, et al: Targeting FOXA1-mediated repression of TGF- $\beta$ signaling suppresses castration-resistant prostate cancer progression. J Clin Invest 129: 569-582, 2019

59. Gui B, Gui F, Takai T, Feng C, Bai X, Fazli L, Dong X, Liu S, Zhang X, Zhang W, et al: Selective targeting of PARP-2 inhibits androgen receptor signaling and prostate cancer growth through disruption of FOXA1 function. Proc Natl Acad Sci USA 116 14573-14582, 2019.

60. Xu W, Yang H, Liu Y, Yang Y, Wang P, Kim SH, Ito S, Yang C, Wang P, Xiao MT, et al: Oncometabolite 2-hydroxyglutarate is a competitive inhibitor of $\alpha$-ketoglutarate-dependent dioxygenases. Cancer Cell 19: 17-30, 2011.

61. Ghiam AF, Cairns RA, Thoms J, Dal Pra A, Ahmed O, Meng A, Mak TW and Bristow RG: IDH mutation status in prostate cancer. Oncogene 31: 3826, 2012.

62. Mondesir J, Willekens C, Touat M and de Botton S: IDH1 and IDH 2 mutations as novel therapeutic targets: Current perspectives. J Blood Med 7: 171-180, 2016.

63. Wu YM, Cieślik M, Lonigro RJ, Vats P, Reimers MA, Cao X, Ning Y, Wang L, Kunju LP, de Sarkar N, et al: Inactivation of CDK12 delineates a distinct immunogenic class of advanced prostate cancer. Cell 173: 1770-1782.e14, 2018

64. Tomlins SA, Rhodes DR, Yu J, Varambally S, Mehra R, Perner S, Demichelis F, Helgeson BE, Laxman B, Morris DS, et al: The role of SPINK1 in ETS rearrangement-negative prostate cancers. Cancer Cell 13: 519-528, 2008

65. Hermans KG, van Marion R, van Dekken H, Jenster G, van Weerden WM and Trapman J: TMPRSS2:ERG fusion by translocation or interstitial deletion is highly relevant in androgen-dependent prostate cancer, but is bypassed in late-stage androgen receptor-negative prostate cancer. Cancer Res 66: 10658-10663, 2006

66. Thangapazham R, Saenz F, Katta S, Mohamed AA, Tan SH Petrovics G, Srivastava S and Dobi A: Loss of the NKX3.1 tumorsuppressor promotes the TMPRSS2-ERG fusion gene expression in prostate cancer. BMC Cancer 14: 16, 2014.

67. Fontugne J, Davis K, Palanisamy N, Udager A, Mehra R, McDaniel AS, Siddiqui J, Rubin MA, Mosquera JM and Tomlins SA: Clonal evaluation of prostate cancer foci in biopsies with discontinuous tumor involvement by dual ERG/ SPINK1 immunohistochemistry. Mod Pathol 29: 157-165, 2016

68. Løvf M, Zhao S, Axcrona U, Johannessen B, Bakken AC, Carm KT, Hoff AM, Myklebost O, Meza-Zepeda LA and Lie AK: Multifocal primary prostate cancer exhibits high degree of genomic heterogeneity. Eur Urol 75: 498-505, 2019.

69. Huang CC, Deng FM, Kong MX, Ren Q, Melamed J and Zhou M: Re-evaluating the concept of 'dominant/index tumor nodule' in multifocal prostate cancer. Virchows Arch 464: 589-594, 2014.

70. McNeal JE, Price HM, Redwine EA, Freiha FS and Stamey TA: Stage A versus stage B adenocarcinoma of the prostate: Morphological comparison and biological significance. J Urol 139: 61-65, 1988

71. Liu W, Laitinen S, Khan S, Vihinen M, Kowalski J, Yu G, Chen L, Ewing CM, Eisenberger MA, Carducci MA, et al: Copy number analysis indicates monoclonal origin of lethal metastatic prostate cancer. Nat Med 15: 559-565, 2009.

72. Haffner MC, Mosbruger T, Esopi DM, Fedor H, Heaphy CM, Walker DA, Adejola N, Gürel M, Hicks J, Meeker AK, et al: Tracking the clonal origin of lethal prostate cancer. J Clin Invest 123: 4918-4922, 2013

73. Barry M,Perner S, Demichelis F and Rubin MA: TMPRSS2-ERG fusion heterogeneity in multifocal prostate cancer: clinical and biologic implications. Urology 70: 630-633, 2007.

74. Furusato B, Gao CL, Ravindranath L, Chen Y, Cullen J, McLeod DG, Dobi A, Srivastava S, Petrovics G and Sesterhenn IA: Mapping of TMPRSS2-ERG fusions in the context of multi-focal prostate cancer. Mod Pathol 21: 67-75, 2008.

75. Yoshimoto M, Ding K, Sweet JM, Ludkovski O, Trottier G, Song KS, Joshua AM, Fleshner NE, Squire JA and Evans AJ: PTEN losses exhibit heterogeneity in multifocal prostatic adenocarcinoma and are associated with higher Gleason grade. Mod Pathol 26: 435-447, 2013

76. Boutros PC, Fraser M, Harding NJ, de Borja R, Trudel D, Lalonde E, Meng A, Hennings-Yeomans PH, McPherson A, Sabelnykova VY, et al: Spatial genomic heterogeneity within localized, multifocal prostate cancer. Nat Genet 47: 736-745, 2015.
77. Cooper CS, Eeles R, Wedge DC, Van Loo P, Gundem G, Alexandrov LB, Kremeyer B, Butler A, Lynch AG, Camacho N, et al: Analysis of the genetic phylogeny of multifocal prostate cancer identifies multiple independent clonal expansions in neoplastic and morphologically normal prostate tissue. Nat Genet 47: 367-372, 2015.

78. Crawford ED, Heidenreich A, Lawrentschuk N, Tombal B, Pompeo ACL, Mendoza-Valdes A, Miller K, Debruyne FMJ and Klotz L: Androgen-targeted therapy in men with prostate cancer: Evolving practice and future considerations. Prostate Cancer Prostatic Dis 22: 24-38, 2019.

79. Vickers AJ, Bianco FJ, Serio AM, Eastham JA, Schrag D, K EA, Reuther AM, Kattan MW, Pontes JE and Scardino PT: The surgical learning curve for prostate cancer control after radical prostatectomy. J Natl Cancer Inst 99: 1171-1177, 2007.

80. Yu EY, Gulati R, Telesca D, Jiang P, Tam S, Russell KJ, Nelson PS, Etzioni RD and Higano CS: Duration of first off-treatment interval is prognostic for time to castration resistance and death in men with biochemical relapse of prostate cancer treated on a prospective trial of intermittent androgen deprivation. J Clin Oncol 28: 2668-2673, 2010

81. Huang KC, Evans A, Donnelly B and Bismar TA: SPINK1 Overexpression in localized prostate cancer: A rare event inversely associated with ERG expression and exclusive of homozygous PTEN deletion. Pathol Oncol Res 23: 399-407, 2017.

82. Green SM, Mostaghel EA and Nelson PS: Androgen action and metabolism in prostate cancer. Mol Cell Endocrinol 360: 3-13, 2012.

83. Phin S, Moore MW and Cotter PD: Genomic rearrangements of PTEN in prostate cancer. Front Oncol 3: 240, 2013.

84. Taylor BS, Schultz N, Hieronymus H, Gopalan A, Xiao Y, Carver BS, Arora VK, Kaushik P, Cerami E, Reva B, et al: Integrative genomic profiling of human prostate cancer. Cancer Cell 18: 11-22, 2010

85. Zhang J, Cunningham JJ, Brown JS and Gatenby RA: Integrating evolutionary dynamics into treatment of metastatic castrate-resistant prostate cancer. Nat Commun 8: 1816, 2017.

86. Lawson DA, Zong Y, Memarzadeh S, Xin L, Huang J and Witte ON: Basal epithelial stem cells are efficient targets for prostate cancer initiation. Proc Natl Acad Sci USA 107: 2610-2615, 2010

87. Zhang D, Park D, Zhong Y, Lu Y, Rycaj K, Gong S, Chen X, Liu X, Chao HP, Whitney $\mathrm{P}$, et al: Stem cell and neurogenic gene-expression profiles link prostate basal cells to aggressive prostate cancer. Nat Commun 7: 10798, 2016.

88. Nouri M, Caradec J, Lubik AA, Li N, Hollier BG, Takhar M Altimirano-Dimas M, Chen M, Roshan-Moniri M, Butler M, et al: Therapy-induced developmental reprogramming of prostate cancer cells and acquired therapy resistance. Oncotarget 8: 18949-18967, 2017

89. Wu C, Wyatt AW, Lapuk AV, McPherson A, McConeghy BJ, Bell RH, Anderson S, Haegert A, Brahmbhatt S, Shukin R, et al: Integrated genome and transcriptome sequencing identifies a novel form of hybrid and aggressive prostate cancer. J Pathol 227: 53-61, 2012.

90. Lipianskaya J, Cohen A, Chen CJ, Hsia E, Squires J, Li Z, Zhang Y, Li W, Chen X, Xu H and Huang J: Androgen-deprivation therapy-induced aggressive prostate cancer with neuroendocrine differentiation. Asian J Androl 16: 541-544, 2014.

91. Aparicio AM, Harzstark AL, Corn PG, Wen S, Araujo JC, Tu SM, Pagliaro LC, Kim J, Millikan RE, Ryan C, et al: Platinum-based chemotherapy for variant castrate-resistant prostate cancer. Clin Cancer Res 19: 3621-3630, 2013.

92. Bonkhoff $\mathrm{H}$ and Remberger K: Differentiation pathways and histogenetic aspects of normal and abnormal prostatic growth: A stem cell model. Prostate 28: 98-106, 1996.

93. Cortés MA, Cariaga-Martinez AE,Lobo MV,Martín Orozco RM, Motiño O, Rodríguez-Ubreva FJ, Angulo J, López-Ruiz P and Colás B: EGF promotes neuroendocrine-like differentiation of prostate cancer cells in the presence of LY294002 through increased ErbB2 expression independent of the phosphatidylinositol 3-kinase-AKT pathway. Carcinogenesis 33: 1169-1177, 2012.

94. Abrahamsson PA, Wadström LB, Alumets J, Falkmer S and Grimelius L: Peptide-hormone- and serotonin-immunoreactive tumour cells in carcinoma of the prostate. Pathol Res Pract 182: 298-307, 1987.

95. Thompson J, Hyytinen ER, Haapala K, Rantala I, Helin HJ, Jänne OA, Palvimo JJ and Koivisto PA: Androgen receptor mutations in high-grade prostate cancer before hormonal therapy. Lab Invest 83: 1709-1713, 2003. 
96. Röpke A, Erbersdobler A, Hammerer P, Palisaar J, John K, Stumm M and Wieacker P: Gain of androgen receptor gene copies in primary prostate cancer due to $\mathrm{X}$ chromosome polysomy. Prostate 59: 59-68, 2004.

97. Nouri M, Ratther E, Stylianou N, Nelson CC, Hollier BG and Williams ED: Androgen-targeted therapy-induced epithelial mesenchymal plasticity and neuroendocrine transdifferentiation in prostate cancer: An opportunity for intervention. Front Oncol 4: 370, 2014.

98. Han G, Buchanan G, Ittmann M, Harris JM, Yu X, Demayo FJ, Tilley W and Greenberg NM: Mutation of the androgen receptor causes oncogenic transformation of the prostate. Proc Natl Acad Sci USA 102: 1151-1156, 2005.

99. Kaarbø M, Mikkelsen OL, Malerød L, Qu S, Lobert VH, Akgul G, Halvorsen T, Maelandsmo GM and Saatcioglu F: PI3K-AKT-mTOR pathway is dominant over androgen receptor signaling in prostate cancer cells. Cell Oncol 32: 11-27, 2010.

100. Terry $\mathrm{S}$ and Beltran $\mathrm{H}$ : The many faces of neuroendocrine differentiation in prostate cancer progression. Front Oncol 4: 60, 2014.

101. Choi N, Zhang B, Zhang L, Ittmann M and Xin L: Adult murine prostate basal and luminal cells are self-sustained lineages that can both serve as targets for prostate cancer initiation. Cancer Cell 21: 253-265, 2012

102. Germann M, Wetterwald A, Guzmán-Ramirez N, vander Pluijm G, Culig Z, Cecchini MG, Williams ED and Thalmann GN: Stem-like cells with luminal progenitor phenotype survive castration in human prostate cancer. Stem Cells 30: 1076-1086, 2012.
103. Evans AJ, Humphrey PA, Belani J, van der Kwast TH and Srigley JR: Large cell neuroendocrine carcinoma of prostate: A clinicopathologic summary of 7 cases of a rare manifestation of advanced prostate cancer. Am J Surg Pathol 30: 684-693, 2006 .

104. Chen H, Sun Y, Wu C, Magyar CE, Li X, Cheng L, Yao JL, Shen S, Osunkoya AO, Liang C and Huang J: Pathogenesis of prostatic small cell carcinoma involves the inactivation of the P53 pathway. Endocr Relat Cancer 19: 321-331, 2012.

105. Beltran H, Prandi D, Mosquera JM, Benelli M, Puca L, Cyrta J, Marotz C, Giannopoulou E, Chakravarthi BV, Varambally S, et al: Divergent clonal evolution of castration-resistant neuroendocrine prostate cancer. Nat Med 22: 298-305, 2016.

106. Aparicio A, Logothetis CJ and Maity SN: Understanding the lethal variant of prostate cancer: Power of examining extremes. Cancer Discov 1: 466-468, 2011.

cc) (i) (3) This work is licensed under a Creative Commons c. AY No No Attribution-NonCommercial-NoDerivatives 4.0 International (CC BY-NC-ND 4.0) License. 